\title{
Financial and Capital Market Commission Financing: Aspects and Challenges
}

\author{
Rita Vanaga, Biruta Sloka \\ University of Latvia, Faculty of Business, Management and Economics, Aspazijas \\ bulv. 5, Riga, Latvia \\ ritava@inbox.lv,biruta.sloka@lu.lv
}

\begin{abstract}
Finance regulators are very important institutions for normal economic development of the country and good international cooperation in great extent depend from efficient work of finance regulator. Finance regulator must be properly financed and this is also e very important aspect which is analysed also by academic researchers in many countries around the globe. Aim of current research paper is to investigate possible developments of finance regulator financing based on analysis of expert views on possible future developments of finance regulator financing. Research methods applied: analysis of scientific publications and previous conducted research, analysis of legislative documents on finance regulator financing, expert survey. Data of expert survey is analysed by indicators of descriptive statistics: indicators of central tendency or location and indicators of variability. The results of the expert survey have indicated that there must be prepared regulations for better motivation of market participants from one side and acceptable financing of finance regulator from other side.
\end{abstract}

Keywords: finance regulator, financing of finance regulator, financing arrangements.

\section{Introduction}

The relatively recent global crisis has highlighted the need for supervisory models to change and the importance of regulation in the financial system, both nationally and globally. Recent developments in banking sector in Latvia especially related with PNB Bank where bank accounts of many retired people were located leads to requirements for proficiency of Finance Regulator which has to be efficiently financed, stable and professional. In different countries Finance Regulators have different models of their financing. The Single Supervisory Mechanism was established in Europe at the end of 2014, reinforcing macro-prudential supervision, 
which focuses on ensuring stability at the level of individual financial institutions to ensure the stability of the financial system as a whole and cooperation between ECB and EU competent authorities (financial market supervisors) (FKTK, 2014). Financial and capital market regulation and supervision in Latvia has become more prominent in 2018, with particular attention to certain aspects of supervision and its importance in combating financial crime in a global context. Due to the weaknesses of the financial system, as demonstrated by the situation with AS ABLV Bank, risk reduction in the financial sector has been initiated in Latvia, which in turn leads to a significant outflow of financing from Latvian banks. The share of foreign deposits in Latvian commercial banks in September 2019 is 19.5\%, since 2015 this proportion has decreased by 34 pp (FKTK, 2019). This, in turn, poses a risk to the financing of the Latvian financial regulator.

In 2019, the banking sector is still questioning the public in the shadow financial supervision segment, as five Latvian commercial banks, which are almost a third of Latvian commercial banks, are exposed to high risk. This is also evidenced by the suspension and liquidation of AS PNB Banka, where many pensioners had their money. In addition to the ability of the financial regulator to be effectively funded, there is a very significant ability to communicate with the public about financial literacy issues

The status of the Latvian financial regulator analyzed in the study is a derivative public entity with the status of an autonomous public authority and with its own resources, and its purpose is to regulate and supervise the Latvian financial and capital market and its members and to encourage investors, depositors and insurers, protection of personal interests and development and stability of the financial and capital market in Latvia.

The topic of the research is topical because the financing of the Latvian financial regulator has become very topical both for the regulator and society, because finance regulator needs to obtain the necessary funds for its financing. The financial market regulator needs to develop a financing model that can cover the operating costs of the regulator, as well as capital and development-oriented costs, both for research, functional audits and change management consultancy, in order to fulfil its regulatory and the priorities set in the monitoring strategy. In order for the financial regulator to purposefully provide the prerequisites for it to function as a modern and socially beneficial organization that ensures systemic protection of clients' interests and financial market stability, safe financial market regulation according to Latvian conditions, it needs an appropriate financing management solution corresponding with best praxis in developed counties.

The aim of the study was to study the financing models in the world for financial and capital market supervisors, and to find out the financial and capital market supervisors' opinion with the results of the survey and financial sector experts with the results of the Latvian financial regulator principles for improving the financial 
regulator's finances.

The research question was to ensure the sustainability of the FCMC's funding, is there a need to change the FCMC's funding principles?

Tasks of the research included analysing special literature on sustainable financial planning, analyzing financing models of foreign financial sector supervisors, analysing the activities of Latvian financial regulator and regulating its activities, including financing legislation, as well as financial sector expert, opinion on the current financing model of the Latvian financial regulator and possible changes, to find out the opinion of Latvian financial and capital market participants on the financing of their supervision, to analyse and evaluate the FCMC's goals, tasks for sustainable development.

The research methods were scientific literature and legislation of the Republic of Latvia, foreign law, data analysis published by foreign competent authorities; the justification of their application are based on scientific articles, publications, databases and internet resources of empirical management scientists and economists and empirical methods: empirical data acquisition method - expert survey of financial and capital market participants, as well as industry experts' survey;, data processing methods (qualitative data processing with discourse analysis, quantifiable questions with descriptive statistics characteristics - central tendency or location indices (arithmetic mean, mode, median), indicators of variability - range, standard deviation, standard error of arithmetic mean, cross - tabulations, correlation analysis, factor analysis with varimax rotation. Empirical data analysis performed with SPSS data processing software.

\section{Theoretical findings in literature review}

Structural reforms of financial system regulators in the world have motivated also academic researchers to devote their attention and results to different aspects often having very serious consequences.

The rapid development of the financial system has led to structural reforms of financial regulators, which also include financing issues (Holland, 2009; Palepu, et al. 2008), security issues (Davidaviciene, et al. 2019) as well as role of the government in financial sector development (Cooray, 2011; Christensen and Laegreid, 2011; Novoa and Seeling, 2009; Qiao, 2013), having very big importance on public sector accountability, experience and reputation (Schillermans, 2016; Bovens, et al. 2014), taking into account that very important is the qualification and experience of the staff (Raudeliuniene and Szarucki, 2019; Holland, 2019) and taking into account and serious consideration that there is a very big influence of globalisation and digital economy (Zekos, 2003; Preda, 2005).

Researchers have stressed that "in the context of globalization and transformations, the knowledge potential management is an effective tool for increasing the effectiveness of organizations" (Raudeliuniene, et al. 2018). 
Critical reflections of problematics of financialisation have to be serious considered (Haslam, 2010) and serious attention to be paid to several aspects of money loundering risk (De Koker, 2009) and sharing sensitive information (Murphy, 2006). Experience in other countries and bank crisis lessons have to be taken into account in researched in detail (Fallon, 2015; Lift and Wahlstrom, 2018).

Supervision and regulation of the financial sector is vital to the development of the financial system and the economy. In Latvia, the stability, competitiveness and development of the financial and capital market are promoted by official institutions preparing normative documents regulating the finance and capital market (Saeima, 2000), finance and capital market commission (FKTK 2014 and 2019) and institutions evaluating the results (Supreme Court of Republic of Latvia, 2019 and 2015).

\section{Empirical research results and discussion on characteristics of the factors indicating the financial market of Latvia for the structure of financing}

In order to find out the opinion of Latvian financial market subjects on FCMC financing issues and their close relation with the supervision and regulation service provided by the FCMC, a targeted survey was conducted - to find out and summarize the views of market participants: (1) the most appropriate components for determining funding; (2) the adequacy of the payment base to market participants; (3) on changes in the financing of the functions of the FCMC; and (4) the independence of supervision and the adequacy of the payment for the service.

This study will analyze survey questions that address factors that share common features in the relationship between a supervisor / regulator service and funding, or the size, relevance, distribution, or other proportion of funding. At the end of 2017, the FCMC oversaw 309 market participants, but by mid-2018 they were already 314 without capital market participants.

The survey included 43 insurance market participants, 24 monetary financial institutions, 7 monetary non-financial institutions, 14 financial instruments and seven private pension funds. Unfortunately, neither officials of the depositary, the stock exchange nor the issuers have participated in the survey.

The financial market participants were asked to evaluate 11 statements which the financial market participants had to evaluate on a scale of 1 to 10 . The scale evaluated the extent to which the respondent agreed with these analysed statements, with 1 strongly disagreeing and 10 strongly agreeing.

The analysis of the evaluations to the 11 analysed statements with reduction of initial factors by one of the most often used multivariate analysis method factor analysis led to the conclusion that they are united by common factors resulting from a complex factor analysis, the results of which are presented in Table 1. 
Table 1: Results of factor analysis of expert evaluations

\begin{tabular}{|c|c|c|c|c|}
\hline \multirow{2}{*}{ Initial factors evaluated by experts } & \multicolumn{4}{|c|}{ Complex Factors } \\
\hline & 1 & 2 & 3 & 4 \\
\hline $\begin{array}{l}\text { FCMC funding to be provided by market participants (those } \\
\text { overseen by the Financial and Capital Market Commission) }\end{array}$ & 0,454 & 0,755 & 0,066 & $-0,025$ \\
\hline $\begin{array}{l}\text { Direct financing through payments from market participants } \\
\text { provides independent market monitoring and regulation }\end{array}$ & 0,437 & 0,812 & 0,022 & $-0,071$ \\
\hline $\begin{array}{l}\text { The payment base currently set for the market participant you } \\
\text { represent is adequate for determining the payments for FCMC } \\
\text { financing }\end{array}$ & 0,849 & 0,132 & 0,000 & 0,019 \\
\hline $\begin{array}{l}\text { The amount charged to market participants is currently fair } \\
\text { across market segments (conditionally related to industry } \\
\text { monitoring / regulatory costs) }\end{array}$ & 0,798 & 0,149 & $-0,018$ & 0,010 \\
\hline $\begin{array}{l}\text { Market participants should provide / finance supervision / } \\
\text { regulation of other market participants (if a segment is small / } \\
\text { underdeveloped / other reasons) }\end{array}$ & 0,149 & $-0,109$ & 0,803 & 0,034 \\
\hline $\begin{array}{l}\text { Market participants should be categorized according to their } \\
\text { risk profile and, accordingly, be assigned an increase in funding } \\
\text { for riskier market participants and a reduction in funding for } \\
\text { less risky market participants }\end{array}$ & $-0,050$ & 0,379 & 0,631 & $-0,332$ \\
\hline $\begin{array}{l}\text { Market participants are to be classified according to their size, } \\
\text { grouped into groups and fixed for each year according to their } \\
\text { size }\end{array}$ & $-0,010$ & 0,198 & 0,679 & 0,163 \\
\hline $\begin{array}{l}\text { All market participants need to set a minimum annual fee to } \\
\text { fund the FCMC }\end{array}$ & 0,002 & 0,572 & 0,345 & 0,229 \\
\hline $\begin{array}{l}\text { It is necessary to limit the maximum annual payments to all } \\
\text { market participants in the financing of the FCMC }\end{array}$ & $-0,306$ & 0,302 & 0,029 & 0,754 \\
\hline $\begin{array}{l}\text { Financial technology start-ups, which represent the innovative } \\
\text { segment, should facilitate the financing of the FCMC }\end{array}$ & 0,333 & $-0,171$ & 0,066 & 0,775 \\
\hline $\begin{array}{c}\text { Payment made to FCMC provides appropriate monitoring / } \\
\text { regulation service }\end{array}$ & 0,695 & 0,216 & 0,148 & 0,030 \\
\hline
\end{tabular}

Source: Author's construction based on Rita Vanaga conducted expert survey in 2019,

Evaluation scale 1-10, where 1- not important; 10-very important

As result of factor analysis with extraction of complex factors with Principal Component Analysis with varimax rotation method with Kaiser normalisation in 
rotation which converted in 8 iterations there were identified four complex factors indicating main principles could be taken into account from big amount of initial factors.

Factor analysis focused the factors - the authors' calculations show four complex factors for the initially 11 identified factors:

Complex Factor I: Finance market participants' satisfaction with existing financing arrangements: consisting of initial factors: The payment base currently set by the market participant you represent is adequate for determining payments to the FCMC; The level of the fee charged to market participants is currently fair across market segments (determined relatively according to industry monitoring / regulatory costs); Payment made FCMC provides appropriate monitoring / regulation service.

Complex Factor II: Supervisory interaction (and its financing) factor consisting of initial factors: The FCMC must be funded by market participants (those supervised by the FCMC); Direct financing through market participant payments provides independent market monitoring and regulation; All market participants need to set a minimum annual fee to fund the FCMC.

Complex Factor III: The classification factor for market participants consisting of initial factors: Market participants should quote / finance supervision / regulation of other market participants (if segment is small / underdeveloped / new segment or other reasons); Market participants should be categorized according to their risk profile and, accordingly, be assigned an increase in funding for a more risky player and a decrease in funding for a less risky player; Market participants should be categorized according to their size by grouping them and fixing a fixed level of funding according to their size on an annual basis.

Complex Factor IV: Factor in the granting of incentives to market participants consisting of initial factors: It is necessary to limit the maximum annual payments to all market participants in the financing of the FCMC; Financial technology startups, which represent the innovative segment, should facilitate the financing of the FCMC. To analyse deeper the expert opinions it was calculated main indicators of descriptive statistics (arithmetic mean, mode, median, range, standard deviation and standard error of mean on expert evaluations related to finance market participants' satisfaction with existing financing arrangements (complex factor I in factor analysis) - main results are included in table 2 .

As data included in table 2 indicate that the expert views are quite different as the whole evaluation scale is covered with bigger variability for evaluated aspect "The payment base currently set for the market participant you represent is adequate for determining the payments for FCMC financing" with arithmetic mean 6,12 and most often given evaluation - 5, characterised by mode; half of experts gave evaluation 6 or less and half of experts gave evaluation 6 or more (characterised by median). Distribution of evaluations of experts is included in Figure 1. 
Table 2: Main indicators of descriptive statistics on expert evaluations on finance market participants' satisfaction with existing financing arrangements

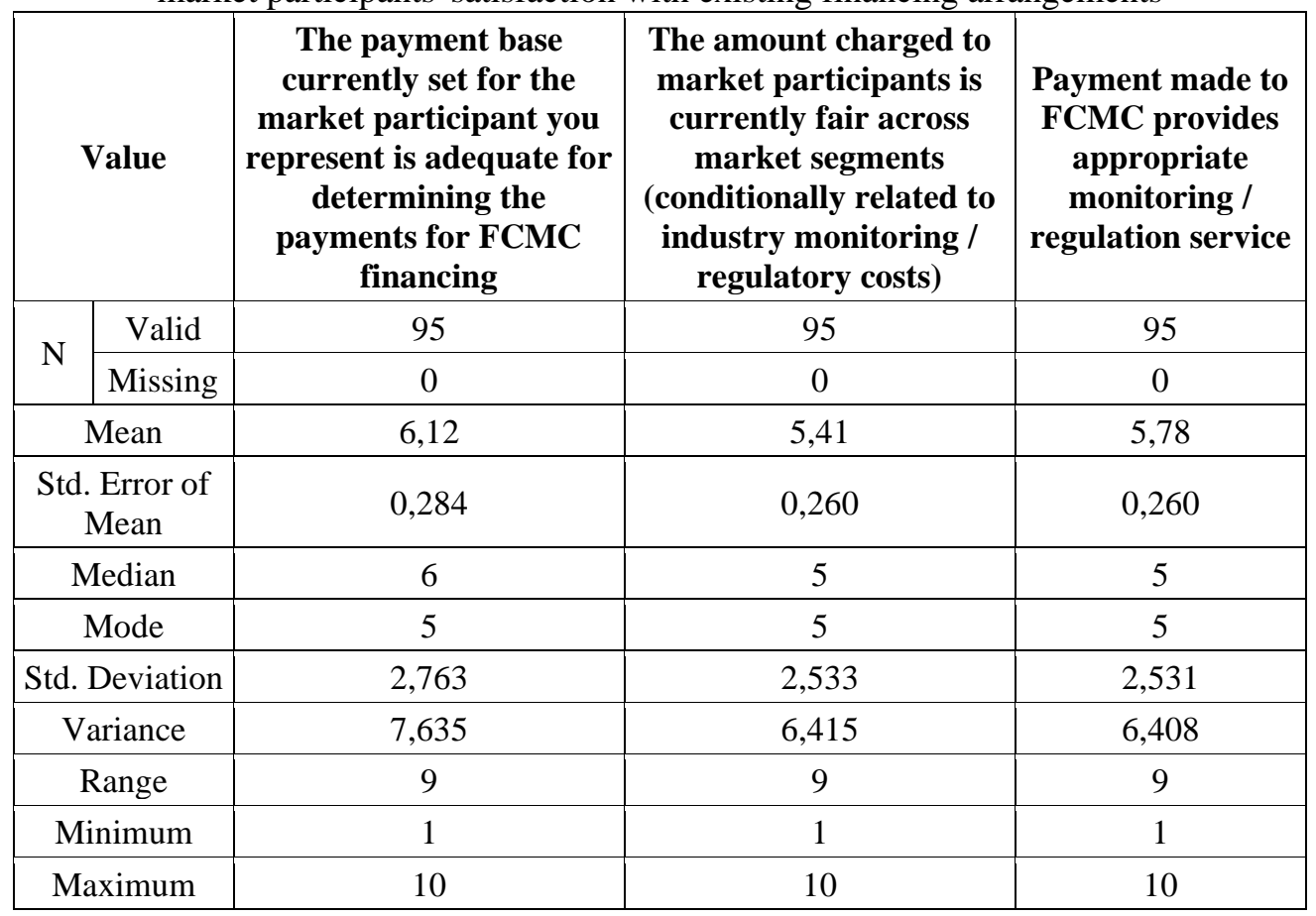

Source: Author's construction based on Rita Vanaga conducted expert survey in 2019,

Evaluation scale 1-10, where 1- not important; 10-very important

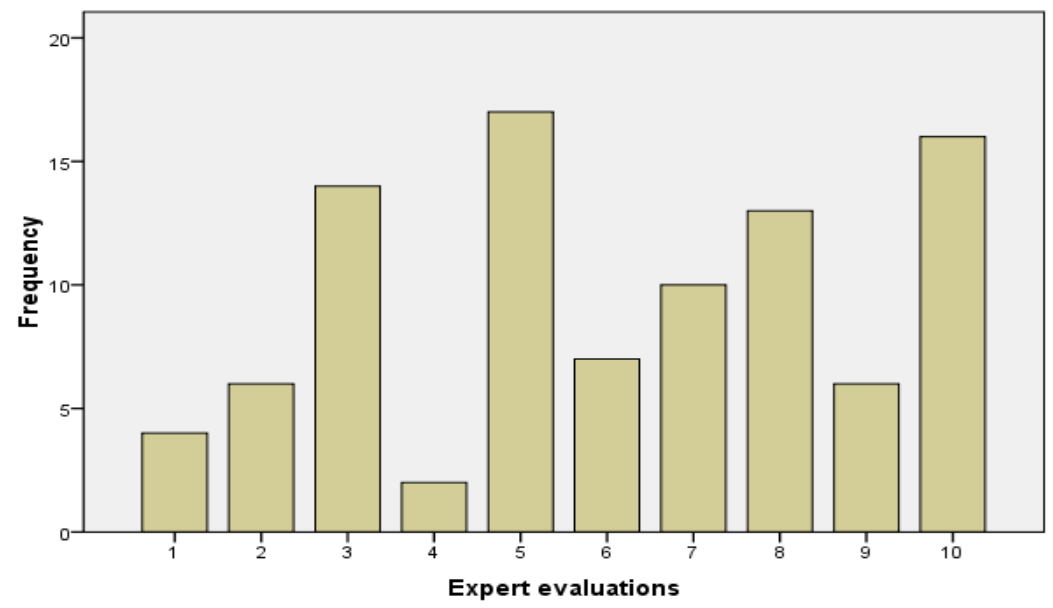

Source: Author's construction based on Rita Vanaga conducted expert survey in 2019,

Evaluation scale 1-10, where 1- not important; 10-very important

Fig.1: Distribution of evaluations by experts on analysed aspect "The payment base currently set for the market participant you represent is adequate for determining the payments for FCMC financing" 
As the evaluations by experts are very different, authors examined how expert evaluations differed according the expert represented company in finance and capital market. Results of expert evaluations on "The amount charged to market participants is currently fair across market segments (conditionally related to industry monitoring / regulatory costs)" by experience is for the company in finance and capital market are included in Table 3.

Table 3: Cross-tabulations by experts on evaluations "The payment base currently set for the market participant you represent is adequate for determining the payments for

FCMC financing" by experience is for the company in finance and capital market

\begin{tabular}{|c|c|c|c|c|c|c|c|}
\hline \multirow{2}{*}{ Evaluations } & \multicolumn{6}{|c|}{ How big experience is for your company in finance and capital market } & Total \\
\cline { 2 - 9 } & $\begin{array}{c}\text { Till one } \\
\text { year }\end{array}$ & 1 to 3years & $\begin{array}{c}3 \text { to } 5 \\
\text { years }\end{array}$ & $\begin{array}{c}5 \text { to } 10 \\
\text { years }\end{array}$ & $\begin{array}{c}10 \text { to } 15 \\
\text { years }\end{array}$ & $\begin{array}{c}\text { more } 15 \\
\text { years }\end{array}$ & \\
\hline 1 & 0 & 0 & 0 & 2 & 2 & 0 & 4 \\
\hline 2 & 1 & 0 & 0 & 2 & 0 & 3 & 6 \\
\hline 3 & 0 & 1 & 0 & 5 & 3 & 5 & 14 \\
\hline 4 & 0 & 0 & 0 & 0 & 1 & 1 & 2 \\
\hline 5 & 0 & 2 & 3 & 0 & 2 & 10 & 17 \\
\hline 6 & 0 & 2 & 0 & 2 & 1 & 2 & 7 \\
\hline 7 & 0 & 0 & 0 & 5 & 3 & 2 & 10 \\
\hline 8 & 0 & 1 & 0 & 3 & 5 & 4 & 13 \\
\hline 9 & 0 & 0 & 0 & 1 & 3 & 2 & 6 \\
\hline 10 & 1 & 0 & 1 & 5 & 3 & 6 & 16 \\
\hline Total & 2 & 2 & 6 & 4 & 25 & 23 & 35 \\
\hline
\end{tabular}

Source: Author's construction based on Rita Vanaga conducted expert survey in 2019,

Evaluation scale 1-10, where 1- not important; 10-very important

As data included in table 2 indicate that the expert views are quite different as the whole evaluation scale is covered with bigger variability for evaluated aspect "The amount charged to market participants is currently fair across market segments (conditionally related to industry monitoring / regulatory costs)" with arithmetic mean 5,41 and most often given evaluation -5 , characterised by mode; half of experts gave evaluation 5 or less and half of experts gave evaluation 5 or more (characterised by median). Distribution of evaluations of experts is included in Figure 2.

As the evaluations by experts are very different, authors examined how expert evaluations differed according the expert represented company in finance and capital market. Results of expert evaluations on "The amount charged to market 
participants is currently fair across market segments (conditionally related to industry monitoring / regulatory costs)" by experience is for the company in finance and capital market are included in Table 4.

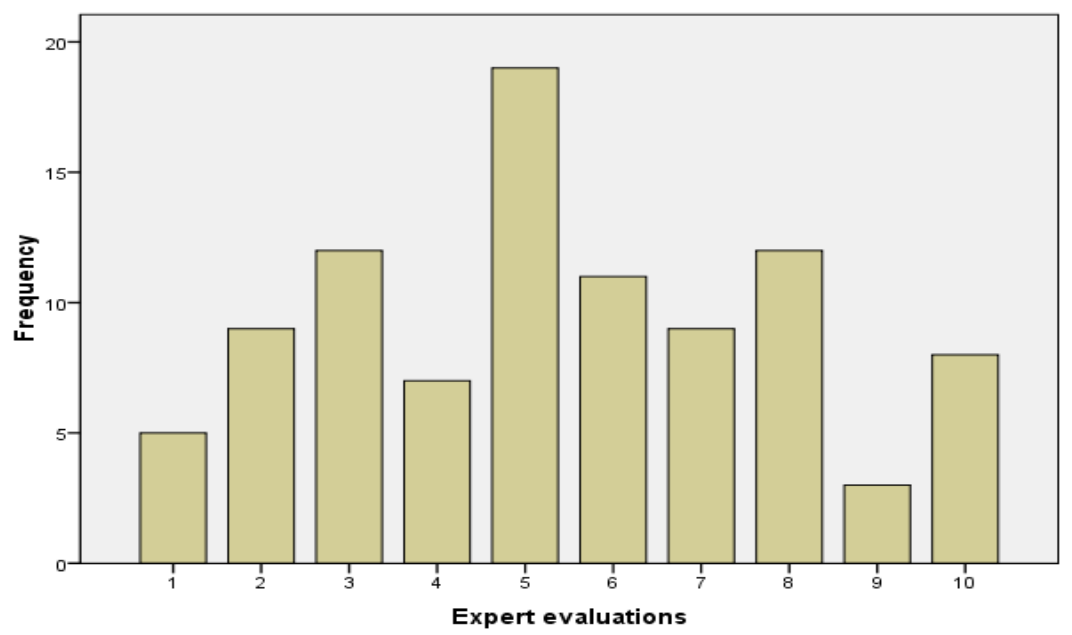

Source: Author's construction based on Rita Vanaga conducted expert survey in 2019,

Evaluation scale 1-10, where 1- not important; 10-very important

Fig. 2: Distribution of evaluations by experts on analysed aspect "The amount charged to market participants is currently fair across market segments (conditionally related to industry monitoring / regulatory costs)"

As data included in table 2 indicate that the expert views are quite different as the whole evaluation scale is covered with bigger variability for evaluated aspect "Payment made to FCMC provides appropriate monitoring / regulation service" with arithmetic mean 5,78 and most often given evaluation -5 , characterised by mode; half of experts gave evaluation 5 or less and half of experts gave evaluation 5 or more (characterised by median). Distribution of evaluations of experts is included in figure 3 .

As the evaluations by experts are very different, authors examined how expert evaluations differed according the expert represented company in finance and capital market. Results of expert evaluations on "Payment made to FCMC provides appropriate monitoring / regulation service" by experience is for the company in finance and capital market are included in Table 5. 
Table 4: Cross-tabulations by experts on evaluations "The amount charged to market participants is currently fair across market segments (conditionally related to industry monitoring / regulatory costs)" by experience is for the company in finance and capital market

\begin{tabular}{|c|c|c|c|c|c|c|c|}
\hline \multirow{2}{*}{ Evaluations } & \multicolumn{6}{|c|}{ How big experience is for your company in finance and capital market } & Total \\
\cline { 2 - 9 } & $\begin{array}{c}\text { Till one } \\
\text { year }\end{array}$ & $\begin{array}{c}1 \text { to } 3 \\
\text { years }\end{array}$ & $\begin{array}{c}3 \text { to } 5 \\
\text { years }\end{array}$ & $\begin{array}{c}5 \text { to } 10 \\
\text { years }\end{array}$ & $\begin{array}{c}10 \text { to } 15 \\
\text { years }\end{array}$ & $\begin{array}{c}\text { more } 15 \\
\text { years }\end{array}$ & \\
\hline 1 & 0 & 0 & 0 & 3 & 1 & 1 & 5 \\
\hline 2 & 0 & 1 & 0 & 2 & 1 & 5 & 9 \\
\hline 3 & 0 & 0 & 0 & 2 & 5 & 5 & 12 \\
\hline 4 & 1 & 0 & 0 & 1 & 3 & 2 & 7 \\
\hline 5 & 1 & 2 & 2 & 5 & 1 & 8 & 19 \\
\hline 6 & 0 & 2 & 1 & 1 & 3 & 4 & 11 \\
\hline 7 & 0 & 1 & 0 & 4 & 2 & 2 & 9 \\
\hline 8 & 0 & 0 & 1 & 2 & 5 & 4 & 12 \\
\hline 9 & 0 & 0 & 0 & 2 & 0 & 1 & 3 \\
\hline 10 & 0 & 0 & 0 & 3 & 2 & 3 & 8 \\
\hline Total & 2 & 6 & 4 & 25 & 23 & 35 & 95 \\
\hline
\end{tabular}

Source: Author's construction based on Rita Vanaga conducted expert survey in 2019,

Evaluation scale 1-10, where 1- not important; 10-very important

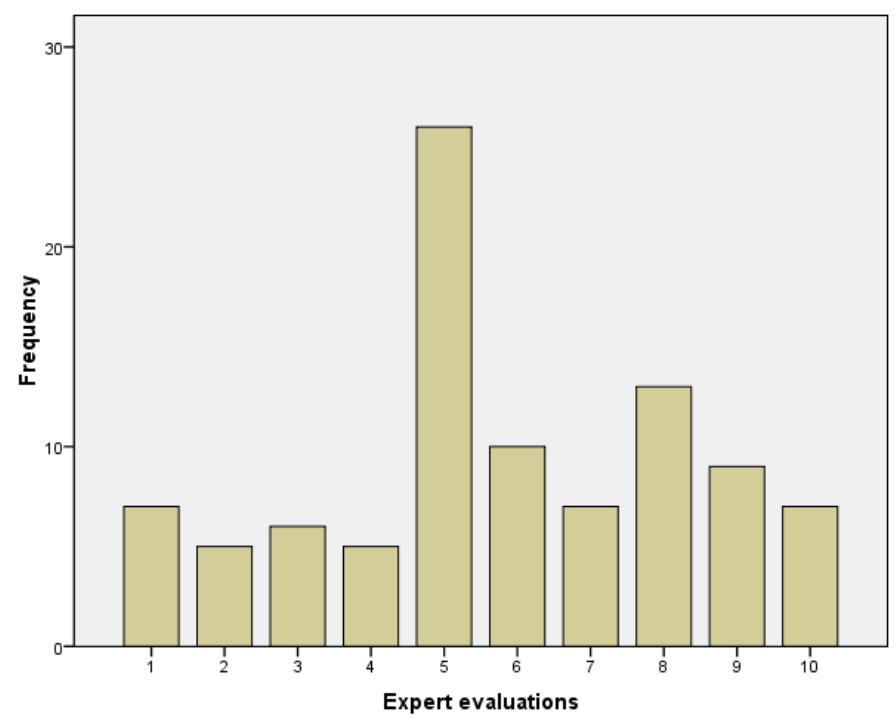

Source: Author's construction based on Rita Vanaga conducted expert survey in 2019,

Evaluation scale 1-10, where 1- not important; 10-very important

Fig. 3: Distribution of evaluations by experts on analysed aspect "Payment made to FCMC provides appropriate monitoring / regulation service" 
Table 5: Cross-tabulations by experts on evaluations "Payment made to FCMC provides appropriate monitoring / regulation service" by experience is for the company in finance and capital market

\begin{tabular}{|c|c|c|c|c|c|c|c|}
\hline \multirow{2}{*}{ Evaluations } & \multicolumn{6}{|c|}{ How big experience is for your company in finance and capital market } & Total \\
\cline { 2 - 8 } & $\begin{array}{c}\text { Till one } \\
\text { year }\end{array}$ & $\begin{array}{c}1 \text { to } 3 \\
\text { years }\end{array}$ & $\begin{array}{c}3 \text { to } 5 \\
\text { years }\end{array}$ & $\begin{array}{c}5 \text { to } 10 \\
\text { years }\end{array}$ & $\begin{array}{c}10 \text { to } 15 \\
\text { years }\end{array}$ & $\begin{array}{c}\text { more } 15 \\
\text { years }\end{array}$ & \\
\hline 1 & 0 & 0 & 0 & 4 & 1 & 2 & 7 \\
\hline 2 & 0 & 0 & 0 & 2 & 2 & 1 & 5 \\
\hline 3 & 0 & 1 & 0 & 3 & 1 & 1 & 6 \\
\hline 4 & 0 & 0 & 0 & 1 & 3 & 1 & 5 \\
\hline 5 & 1 & 2 & 1 & 6 & 4 & 12 & 26 \\
\hline 6 & 0 & 0 & 1 & 1 & 2 & 6 & 10 \\
\hline 7 & 0 & 1 & 0 & 3 & 0 & 3 & 7 \\
\hline 8 & 1 & 1 & 1 & 2 & 4 & 4 & 13 \\
\hline 9 & 0 & 1 & 0 & 2 & 5 & 1 & 9 \\
\hline 10 & 0 & 0 & 1 & 1 & 1 & 4 & 7 \\
\hline Total & 2 & 2 & 6 & 4 & 25 & 23 & 35 \\
\hline
\end{tabular}

Source: Author's construction based on Rita Vanaga conducted expert survey in 2019, Evaluation scale 1-10, where 1- not important; 10-very important

Results indicate that the views of experts are very different even if they are acting for many years (more than 15 years) in finance and capital market.

\section{Conclusion}

Financing of finance and capital market regulator is performed differently in different countries and this is a very important and sensitive aspect influencing in great extent of many sectors of the national economy.

Four main factors could be considered for more efficient finance and capital market financing: Finance market participants' satisfaction with existing financing arrangements; Supervisory interaction (and its financing); The classification factor for market participants; Factor in the granting of incentives to market participants.

Even very big experience in acting in finance and capital markets make different ideas and views on best possible finance regulator financing scheme.

The research was supported by the National Research Programme "Latvian Heritage and Future Challenges for The Sustainability of The State" project "Challenges for The Latvian State and Society and The Solutions in International Context (Interframe-LV)" 


\section{References}

Bovens, M., Schillemans,T., and Goodin. R.E. (2014). Public accountability. In The Oxford Handbook of Public Accountability, edited by M. Bovens, R. E. Goodin, and T. Schillemans, 1-20. Oxford: Oxford University Press.

Christensen, T., and Lægreid. P. (2011). The ashgate research companion to new public management. Farnham: Ashgate.

Cooray, A. (2011). The role of the government in financial sector development. Economic Modelling. 28(3), 928-938.

Davidavičienė, V., Raudeliūnienė, J, Tvaronavičienė, M., and Kaušinis, J. (2019). The importance of security aspects in consumer preferences in electronic environment. Journal of Security and Sustainability Issues, 8(3), 399-411. DOI: 10.9770/jssi.2019, 8, 3(9)

De Koker, L. (2009). Identifying and managing low money laundering risk: perspectives on FATF's risk-based guidance. Journal of Financial Crime, 16(4), 334-352.

Fallon, I. (2015). Black horse ride: The inside story of Lloyds and the banking crisis. Robson Press, London.

FKTK (2014). Vienotais uzraudzības mehānisms (Joint Banking Supervision Mechanism). [Online] Available at https://www.fktk.lv/mediju-telpa/nozarestemati/vienotais-uzraudzibas-mehanisms/kas-jazina-par-vienoto-uzraudzibasmehanismu/. [Accessed 21.04.2020]

FKTK (2019). Banku sektora transformācija (Transfornamation of Banking Sector). [Online] Available at https://www.fktk.lv/wpcontent/uploads/2019/11/INFOGRAFIKA_Q3_2019_LV.pdf. [Accessed 28.04.2020]

Haslam, J. (2010). The problematics of fnancialization: critical reflections. Critical Perspectives on Accounting, 21(7), 642-645.

Holland, J. (2019). Bank top management teams, disclosure, learning, survival and failure - 1990-2017. Qualitative Research in Financial Markets, 11(1), 31-59. 
Holland, J. (2009). Looking behind the Veil'-invisible corporate intangibles, stories, structure and the contextual information content of disclosure. Qualitative Research in Financial Markets, 1(3), 152-187.

Liff, R., and Wahlström, G. (2018). Failed crisis communication: the northern rock bank case. Accounting, Auditing \& Accountability Journal, 31(1), 237-260.

Murphy, D. (2006). Disclosure and sharing of sensitive information: revisiting risk in co-operating regulatory regimes. Journal of Financial Crime, 13(4), 420-441.

Novoa, A., and Seelig, S.S. (2009). Governance practices at financial regulatory and supervisory agencies. IMF.

Palepu, K.G., Healy, P.M., Bernard, V.L., Wright, S., Bradbury, and M., Lee, P. (2008). The role of capital market intermediaries in the dot-com crash of 2000. In Business Analysis and Valuation: Using Financial Statements, 4th ed., Cengage Learning, Boston, MA, 11-19.

Preda,A. (2005). Legitimacy and status groups in financial markets. The British Journal of Sociology, 56(3), 451-471.

Raudeliūnienè, J., Davidavičienè, V., and Jakubavičius, A. (2018). Knowledge management process model. Entrepreneurship and Sustainability Issues, 5(3), 542554. DOI: 10.9770/jesi.2018.5.3(10)

Raudeliuniene, J., and Szarucki, M. (2019). An integrated approach to assessing an organization's knowledge potential, Engineering Economics, 30(1), 69-80. DOI: 10.5755/j01.ee.30.1.20807

Qiao, K. (2013). Government policies and corporate financing decisions in China: theory and evidence. Journal of Systems Science and Systems Engineering, 22(1), 93-111.

Saeima (Parliament of Republic of Latvia) (2000). Law on the financial and capital market commission, accepted 01.06.2000.

Schillemans, T. (2016). Calibrating public sector accountability: translating experimental findings to public sector accountability. Public Management Review, $18,1400-1420$.

Supreme Court of the Republic of Latvia (2019). Summary of court practice in cases of the financial and capital market commission (2006-2018), [Online] 
Available at http://www.at.gov.lv/en/judikatura/tiesu-praksesapkopojumi/administrativas-tiesibas, [Accessed 18.05.2020].

Supreme Court of the Republic of Latvia (2015). Decision of 12 February 2015 in case no. Item 6 of SKA-563/2015 (A43017813).

Zekos, G. (2003). MNEs, Globalisation and digital economy: legal and economic Aspects. Managerial Law, 45(1/2), 1-296. 